\title{
Short Communication: Development of selected PGPR consortium to control Ralstonia syzygii subsp. indonesiensis and promote the growth of tomato
}

\author{
YULMIRA YANTI ${ }^{1, \bullet}$, WARNITA ${ }^{2}$, REFLIN ${ }^{1}$, HASMIANDY HAMID \\ ${ }^{1}$ Department of Plant Protection, Faculty of Agriculture, Universitas Andalas. Jl. Universitas Andalas, Limau Manih, Padang 25163, West Sumatra, \\ Indonesia, Tel.+62-751-72773, Fax.: +62-751-72702, "email: yy.anthie79@gmail.com, mira23@agr.unand.ac.id \\ ${ }^{2}$ Department of Agronomy, Faculty of Agriculture, Universitas Andalas. Padang 25163, West Sumatra, Indonesia
}

Manuscript received: 13 August 2018. Revision accepted: 23 October 2018.

\begin{abstract}
Yanti Y, Warnita, Reflin. 2018. Short Communication: Development of selected PGPR consortium to control Ralstonia syzygii subsp. indonesiensis and promote the growth of tomato. Biodiversitas 19: xxxx. A microbial consortium is a group of different species of microorganisms and acts as a community. Combinations of biocontrol strains are expected to have a better result to suppress multiple plant diseases. Our previous research had selected four plant growth promoting rhizobacteria (PGPR) strains from chili ( $B$. pseudomycoides strain NBRC 101232, B. cereus strain CCM 2010, Bacillus toyonensis strain BCT-7112, Serratia nematodiphila strain DZ0503SBS1) and three strains from tomato (Bacillus pseudomycoides strain NBRC 101232, Bacillus toyonensis strain BCT-7112, Bacillus thuringiensis strain ATCC 10792 ) which had ability to promote growth and control Ralstonia syzygii subsp. indonesiensis indigenously. The strains were used in the development of PGPR consortiums to increase their ability for biocontrol agent of Ralstonia syzigii subsp. indonesiensis and promoting the growth of tomato. Results showed that not all strains had good compatibility to grow together. Ten consortiums were developed based on their compatibilities. All consortiums exhibited the capability to reduce bacterial wilt disease development and also promote the growth of tomato. The consortium consisted of Serratia nematodiphila strain DZ0503SBS1, B. cereus strain CCM 2010, Bacillus aryabhattai strain B8W22 and Bacillus cereus strain IAM 12605 resulted in the best ability to reduce disease development and promote growth and yield of tomato.
\end{abstract}

Keywords: Bacillus; interaction compatibility; PGPR consortium; Serratia

\section{INTRODUCTION}

Bacterial wilt disease caused by Ralstonia syzigii subsp. indonesiensis (former name $R$. solanacearum (Safni et al. 2014)) causes a considerable amount of damage to tomato and many other crops in tropical, subtropical and warm temperate regions of the world ( $\mathrm{Ji}$ et al. 2005). The pathogen is widespread and one of the economically important bacterial plant pathogens (Horita and Tsuchiya 2001). Management of bacterial wilt of tomato was difficult due to the soil-borne nature of the pathogen. Several pesticides had been recommended to be used against this pathogen. However, they were not considered to be long-term solutions due to the concerns of expense, exposure risks, residues, toxicity to non-target organisms and other health and environmental hazards. Nowadays, the idea of controlling soil-borne plant pathogens with chemical pesticides had been shifted to biological control options that might play an important role in agriculture.

Recent studies had been focused on developing ecofriendly, safe, and effective agents for plant pathogens and disease control options (Sundaramoorthy et al. 2012), such as Plant Growth Promoting Rhizobacteria (PGPR). The used of biofertilizers containing PGPR strains might serve as a better alternative and more environmentally friendly practice to improve plant growth through the supply of plant nutrients and increase of soil productivities
(Rajasekar and Elango 2011). PGPR had been well known as the crops biofertilizer (Karlidag et al. 2007), due to the fact that the PGPR strains may promote growth by fixation of atmospheric nitrogen, minerals solubilization (Karthikeyan et al. 2008), and plant growth regulators production (Jaleel et al. 2007). Most of the biocontrol agents used single biocontrol agent against a pathogen in controlling plant disease. This approach had partially reported for its inconsistent performance due to the use of single biocontrol agent is not likely to be active in all ecosystems it was applied or against all the host pathogens. Nowadays, more attention is being concerned with the use of mixed strains of PGPR (Raupach and Kloepper 1998; Nandakumar et al. 2001b; Canaday 2003). Direct interactions that occur among different microbial types often result in the promotion of key processes benefiting plant growth and health. Syntrophic relationships among different microorganisms have been demonstrated in several microbial ecosystems. Therefore, the combination of microorganism inoculants that interacts synergistically was currently being devised, which yield better and quick results (Bashan 1998).

Microbial consortium for plant growth promotion was suggested as a strategy to increase the activity and viability of the PGPR. Each of the constituent strains of the consortium not only outcompetes with the others for rhizospheric establishments, but complement functionally 
for plant growth promotion (Shenoy and Kalagudi 2003). Our previous research had selected four PGPR strains from tomato (B. pseudomycoides strain NBRC 101232, B. cereus strain CCM 2010, Bacillus toyonensis strain BCT-7112, Serratia nematodiphila strain DZ0503SBS1), 3 strains from potato (Bacillus toyonensis strain BCT-7112, Bacillus aryabhattai strain B8W22, Bacillus cereus strain IAM 12605) and 3 strains from chili pepper (Bacillus pseudomycoides strain NBRC 101232, Bacillus toyonensis strain BCT-7112, Bacillus thuringiensis strain ATCC 10792). The strains had the ability to control Ralstonia syzigii subsp. indonesiensis indigenously and promote the growth of chili (Yanti et al. 2017). Developing suitable consortiums are necessary to increase the strains' ability to suppress pathogen attack and also promote growth. This present study purposed to develop consortiums of biocontrol agents to control Ralstonia syzigii subsp. indonesiensis and promote the growth of tomato.

\section{MATERIALS AND METHODS}

\section{Bacteria strain preparation}

All bacteria strains used in this study (Table 1) were separately re-cultured in Nutrient Agar (NA) media in petri-dish by streaking each of the strains to the agar and incubated for $72 \mathrm{~h}$. The pure colony was then used for further study.

\section{Compatibility assay}

All strains were tested for their antagonistic for microbial consortium development following the method of Kumar et al. (2011). The strains were inoculated in Nutrient Broth (NB) and incubated on $110 \mathrm{rpm}$ shaker for $24 \mathrm{~h}$ in room temperature $\left( \pm 27^{\circ} \mathrm{C}\right)$. Two colonies of two different strains were re-suspended with sterile water $\left(10^{7}\right.$ $\mathrm{CFU} / \mathrm{mL}$ ) then sprayed to a petri-dish containing NA and incubated for $24 \mathrm{~h}$. The presence of the inhibition zone was observed for each strain. Each treatment was replicated thrice. The PGPR consortia were developed based on the compatibility of the strains (Table 2).

\section{Development of PGPR consortia}

One pure colony of each strain was inoculated into 25 $\mathrm{mL}$ of $\mathrm{NB}$ in culture bottle $(50 \mathrm{~mL})$ and incubated in rotary shaker $110 \mathrm{rpm}$ for 24 hours. Four $\mathrm{mL}$ of the culture then was transferred to $400 \mathrm{~mL}$ of sterile coconut water in Erlenmeyer flask for the main culture and incubated for $2 \times 24$ hours (Yanti et al. 2017). Suspension of rhizobacteria strains in the coconut water culture was diluted with a comparison to McFarland scale 8 (Density estimated $10^{8}$ $\mathrm{CFU} / \mathrm{mL}$ ). The consortiums (Table 2) were made by mixing the strains with the same volume $(50 \mathrm{~mL} / \mathrm{strain})$ and homogenized.

\section{PGPR consortium assay on tomato}

Tomato seeds were grown in seed tray for 21 days. The seeds were previously dipped in the PGPR consortium for 15 minutes and then sown in the seed tray containing soil and organic manure $(2: 1 \mathrm{v} / \mathrm{v})$. The 21 -days old tomato seedlings were then planted in the polybag containing soil and organic manure $(2: 1 \mathrm{v} / \mathrm{v})$ with previously introduced with the same consortium suspensions by dipping the root in the suspension for 15 minutes. All treatments were replicated three times, with five plants for each unit. No PGPR consortium treatment was applied for control plants.

\section{Pathogens innoculation}

The Ralstonia syzygii subsp. indonesiensis was isolated from infected plants by dipping the stem in sterilized water, and the suspension then streaked in triphenyl tetrazolium (TZC) agar medium. The isolates were then assayed on two weeks old tomato plants to select the most virulence pathogens by injecting $1 \mathrm{~mL}$ of Ralstonia suspension $\left(10^{8}\right.$ $\mathrm{CFU} / \mathrm{mL}$ ) to the tomato plant base stem. The most virulence bacteria (the fastest wilt disease development) was then re-cultured in TZC agar and used for plant disease infection. The pathogen was inoculated on the two weeks old plants by root wounding methods described by Yanti et al. (2018a). The roots were cut in 2 sides of the plants using scissors and poured with $10 \mathrm{~mL}\left(10^{8} \mathrm{CFU} / \mathrm{mL}\right)$ of the $R$. syzigii subsp. indonesiensis suspensions.

Table 1. The strain used for consortium development

\begin{tabular}{lcl}
\hline Strain & Code & $\begin{array}{c}\text { Source of } \\
\text { isolates *) }\end{array}$ \\
\hline B. pseudomycoides strain NBRC 101232 & C1 & Chili plants \\
B. cereus strain CCM 2010 & C2 & \\
Bacillus toyonensis strain BCT-7112 & C3 & \\
Serratia nematodiphila strain DZ0503SBS1 & C4 & \\
& & \\
Bacillus toyonensis strain BCT-7112 & T1 & Tomato \\
Bacillus aryabhattai strain B8W22 & T2 & plants \\
Bacillus cereus strain IAM 12605 & T3 & \\
\hline
\end{tabular}

Note: *) Yanti et al. (2017)

Table 2. PGPR consortia

\begin{tabular}{|c|c|}
\hline Code & Strain \\
\hline $\mathrm{C} 1$ & $\begin{array}{l}\text { S. nematodiphila strain DZ0503SBS1, B. toyonensis } \\
\text { strain BCT-7112, B. aryabhattai } \text { strain B8W22, B. cereus } \\
\text { strain IAM } 12605\end{array}$ \\
\hline $\mathrm{C} 2$ & $\begin{array}{l}\text { S. nematodiphila strain DZ0503SBS1, B. toyonensis } \\
\text { strain BCT-7112 }\end{array}$ \\
\hline C3 & B. aryabhattai strain B8W22, B. cereus strain IAM 12605 \\
\hline $\mathrm{C} 4$ & $\begin{array}{l}\text { oides strain NBRC } 101232, \text { B. cereus strain } \\
\text { toyonensis strain BCT-7112, B. toyonensis } \\
12\end{array}$ \\
\hline $\mathrm{C} 5$ & $\begin{array}{l}\text { B. cereus strain CCM } 2010, \text { B. toyonensis strain BCT- } \\
7112, \text { B. toyonensis strain BCT- } 7112, \text { B. aryabhattai } \\
\text { strain B8W22 }\end{array}$ \\
\hline C6 & B. cereus strain CCM 2010, B. toyonensis strain BCT-7112 \\
\hline $\mathrm{C} 7$ & $\begin{array}{l}\text { B. Pseudomycoides strain NBRC } 101232, \text { B. cereus strain } \\
\text { CCM 2010, B. toyonensis strain BCT-7112, }\end{array}$ \\
\hline $\mathrm{C} 8$ & $\begin{array}{l}\text { B. toyonensis strain BCT-7112, B. aryabhattai strain } \\
\text { B8W22, S. nematodiphila strain DZ0503SBS1 }\end{array}$ \\
\hline C9 & $\begin{array}{l}\text { B. toyonensis strain BCT-7112, S. nematodiphila strain } \\
\text { DZ0503SBS1 }\end{array}$ \\
\hline $\mathrm{C} 10$ & B. cereus strain CCM 2010, B. toyonensis strain BCT-7112 \\
\hline
\end{tabular}




\section{Data collection}

Parameter observed in this research were disease development such as incubation time (observed when the first symptoms of bacterial wilt disease appear) and disease incidence (total of plant diseased until last observation days), and plant growth such as plant height, number of leaves, first flowering time and yields at the first harvest.

Data were analyzed by analysis of variance (ANOVA) at 0.05 probability level. The difference between two means was analyzed using Least Significance Difference (LSD) at 0.05 probability level. All analysis was performed using Statistics 8 Software. Effectivity of all treatments towards control also calculated using the formula of Sivan and Chet (1989).

\section{RESULTS AND DISCUSSION}

\section{Compatibility among bacterial strains}

All PGPR strains were tested for their compatibility. Some of the strains were incompatible showed by the inhibition zone indicating that the strains compete for each other (Table 3 ). The absence of inhibition zone suggesting that the biocontrol agents were compatible (Fig. 1). All the consortiums were further designed based on the compatibility of the strains. $\square$

\section{Growth promoting activity of tomato introduced with PGPR consortiums}

The tomato plant introduced with consortiums had better growth than the control plant, showed from the increase of plant height and leaves number (Table 4). All consortiums could promote tomato heights ranging from 26.95 to $105.19 \%$ compared to control (Fig. 2). Consortium C1 consisted of $S$. nematodiphila strain DZ0503SBS1, $B$. toyonensis strain BCT-7112, B. aryabhattai strain B8W22, $B$. cereus strain IAM 12605 was the best strains combination in increasing plant height and leave number.

Besides promoting the vegetative phase of the tomato plants, the consortia also promoted the generative stage of the plants indicated by the strain's ability in promoting flowering time and yields (Table 4). All consortia increased the yields differently. $\mathrm{C} 1 \quad(S$. nematodiphila strain DZ0503SBS1, $B$. toyonensis strain BCT-7112, B. aryabhattai strain B8W22, B. cereus strain IAM 12605) was the best consortium to accelerate the flowering time and increase yields with an effectivity of $161.9 \%$ compared to control.

Table 3. Compatibility of PGPR strains

\begin{tabular}{|c|c|c|c|c|c|c|c|}
\hline Strain & C1 & $\mathrm{C2}$ & C3 & C4 & T1 & $\mathbf{T 2}$ & T3 \\
\hline $\mathrm{C} 1$ & & & & & & & \\
\hline $\mathrm{C} 2$ & $\sqrt{ }$ & & & & & & \\
\hline C3 & $\sqrt{ }$ & $\sqrt{ }$ & & & & & \\
\hline $\mathrm{C} 4$ & - & - & $\sqrt{ }$ & & & & \\
\hline $\mathrm{T} 1$ & $\sqrt{ }$ & $\sqrt{ }$ & $\sqrt{ }$ & - & & & \\
\hline $\mathrm{T} 2$ & - & $\sqrt{ }$ & $\sqrt{ }$ & $\sqrt{ }$ & $\sqrt{ }$ & & \\
\hline T3 & $\sqrt{ }$ & - & $\sqrt{ }$ & $\sqrt{ }$ & - & $\sqrt{ }$ & \\
\hline
\end{tabular}

incompatible (inhibition zone appear)

Table 4. Plant height and number of leaves of tomato introduced with PGPR consortia

\begin{tabular}{lcccc}
\hline \multirow{2}{*}{ Consortium } & \multicolumn{2}{c}{ Height } & \multicolumn{2}{c}{ Number of leaves } \\
\cline { 2 - 5 } & $\mathbf{( c m )}$ & $\begin{array}{c}\text { Effectivity } \\
(\%)\end{array}$ & (leaves) & $\begin{array}{c}\text { Effectivity } \\
(\%)\end{array}$ \\
\hline C1 & $126.4 \mathrm{a}$ & 105.19 & $54.4 \mathrm{a}$ & 177.55 \\
C2 & $115 \mathrm{~b}$ & 86.69 & $44.8 \mathrm{~b}$ & 128.57 \\
C3 & $111.4 \mathrm{~b}$ & 80.84 & $450 \mathrm{~b}$ & 129.59 \\
C4 & $99.8 \mathrm{c}$ & 62.01 & $37.6 \mathrm{c}$ & 91.84 \\
C5 & $100 \mathrm{c}$ & 62.34 & $37.2 \mathrm{c}$ & 89.8 \\
C6 & $86 \mathrm{~d}$ & 39.61 & $28.8 \mathrm{~d}$ & 46.94 \\
C7 & $81.6 \mathrm{de}$ & 32.47 & $24.8 \mathrm{de}$ & 26.53 \\
C8 & $82.2 \mathrm{de}$ & 33.44 & $24.8 \mathrm{de}$ & 26.53 \\
C9 & $81.6 \mathrm{de}$ & 32.47 & $22.8 \mathrm{ef}$ & 16.33 \\
C10 & $78.2 \mathrm{e}$ & 26.95 & $22.8 \mathrm{ef}$ & 16.33 \\
Control & $61.6 \mathrm{f}$ & & $19.6 \mathrm{f}$ & \\
\hline
\end{tabular}

Note: Values followed by the same letters in the same column differed insignificantly at $5 \%$ probability level according to LSD test

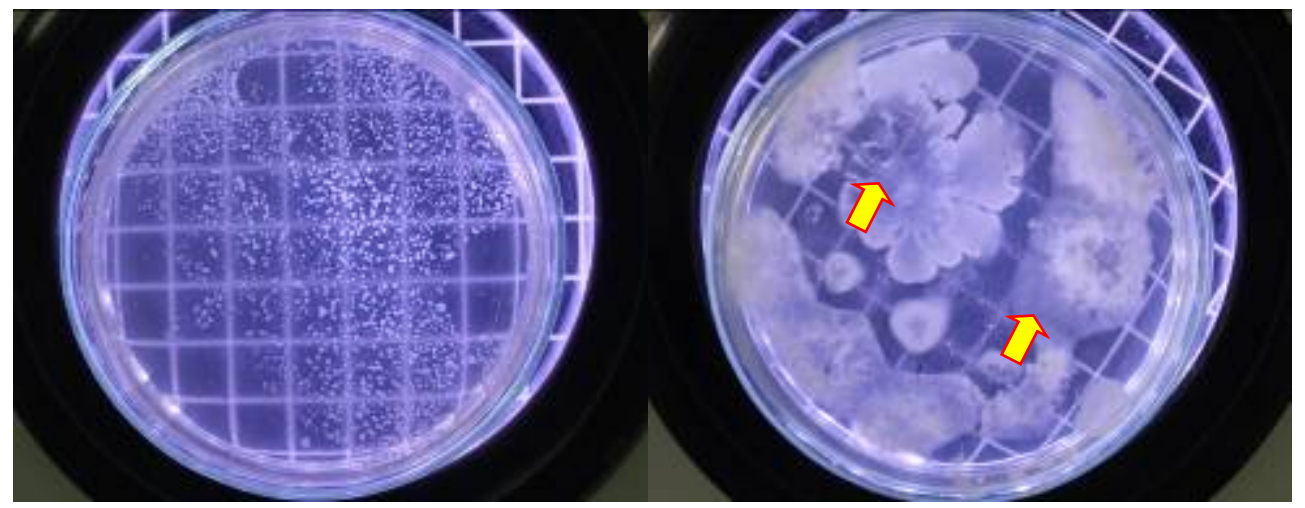

Figure 1. Rhizobacteria compatibility assay, compatible strains (no inhibition zone appear) of $B$. pseudomycoides strain NBRC 101232 and B. cereus strain CCM 2010 (left) and incompatible strains (inhibition zone appear) of B. pseudomycoides strain NBRC 101232 and B. aryabhattai strain B8W22 (right) 


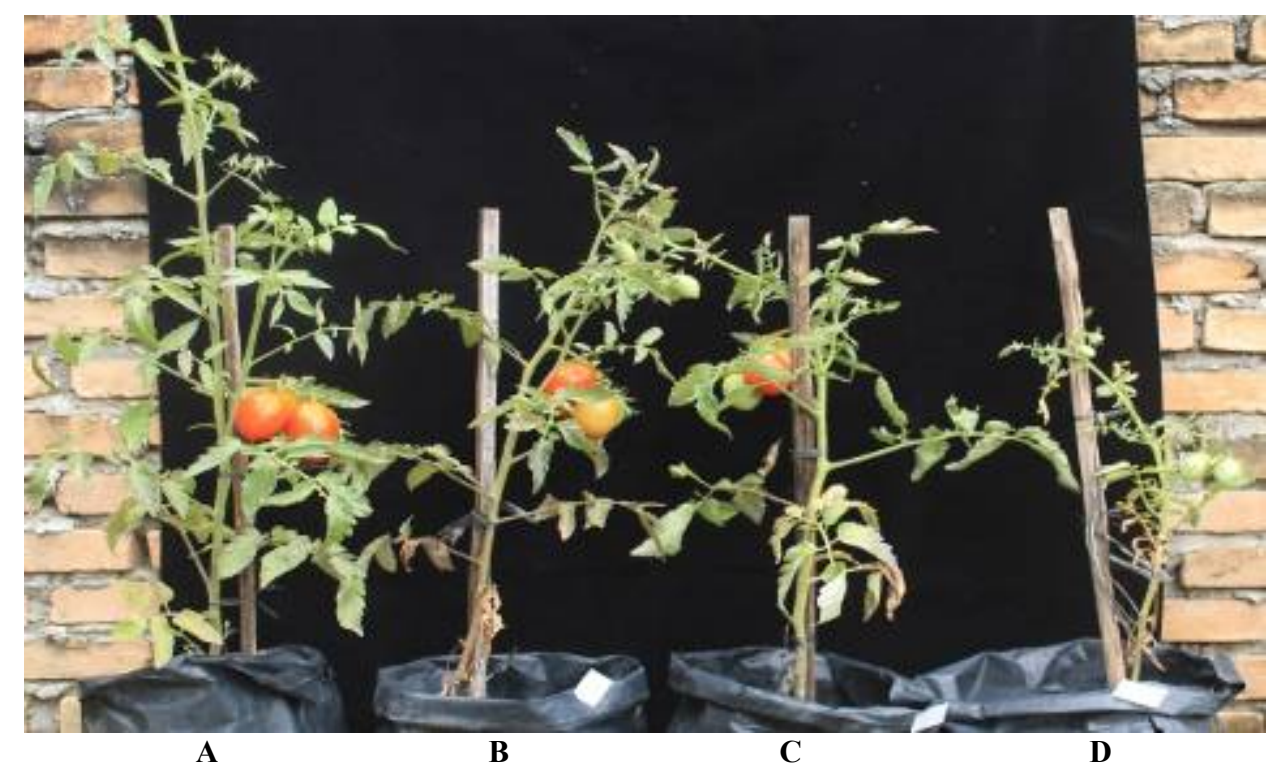

Figure 2. Growth comparison of tomato plants introduced by PGPR consortia. A. C1, B. C2, C. C3, and D. control

Table 4. First flowering time and yields of tomato introduced with PGPR consortiums

\begin{tabular}{|c|c|c|c|c|}
\hline \multirow[b]{2}{*}{ Consortium } & \multicolumn{2}{|c|}{ First flowering time } & \multicolumn{2}{|c|}{ Yields } \\
\hline & $\begin{array}{l}\text { (days after } \\
\text { planting) }\end{array}$ & $\begin{array}{c}\text { Effectivity } \\
(\%)\end{array}$ & (g) & $\begin{array}{c}\text { Effectivity } \\
\text { (\%) }\end{array}$ \\
\hline $\mathrm{C} 1$ & $21.6 \mathrm{f}$ & 50.46 & $260 \mathrm{a}$ & 161.9 \\
\hline $\mathrm{C} 2$ & $25.2 \mathrm{e}$ & 42.2 & $264 \mathrm{a}$ & 157.94 \\
\hline C3 & $27.2 \mathrm{de}$ & 37.61 & 239.6ab & 137.7 \\
\hline $\mathrm{C} 4$ & 27.6de & 36.7 & $215.6 \mathrm{bc}$ & 113.89 \\
\hline $\mathrm{C} 5$ & $280 \mathrm{~d}$ & 35.78 & $198.0 \mathrm{~cd}$ & 96.43 \\
\hline C6 & $31.6 \mathrm{c}$ & 27.52 & $186.0 \mathrm{~d}$ & 84.52 \\
\hline $\mathrm{C} 7$ & $41.6 \mathrm{ab}$ & 4.59 & $152.2 \mathrm{e}$ & 50.99 \\
\hline $\mathrm{C} 8$ & $41.2 \mathrm{ab}$ & 5.5 & $152.2 \mathrm{e}$ & 50.99 \\
\hline C9 & $40.4 \mathrm{~b}$ & 7.34 & $151.4 \mathrm{e}$ & 50.2 \\
\hline $\mathrm{C} 10$ & $42.4 \mathrm{ab}$ & 2.75 & $155.2 \mathrm{e}$ & 53.97 \\
\hline Control & $43.6 \mathrm{a}$ & & $100.8 \mathrm{f}$ & \\
\hline
\end{tabular}

Note: Values followed by the same letters in the same column differed unsignificantly at $5 \%$ probability level according to LSD test

Table 5. Disease development of $R$. syzygii subsp. indonesiensis on tomato introduced with PGPR consortium

\begin{tabular}{lccc}
\hline Consortium & $\begin{array}{c}\text { Incubation time } \\
\text { (days after } \\
\text { inoculation) }\end{array}$ & $\begin{array}{c}\text { Disease } \\
\text { incidence } \\
(\%)\end{array}$ & $\begin{array}{c}\text { Effectivity } \\
\mathbf{( \% )}\end{array}$ \\
\hline C1 & $42.00^{*}$ & 0.00 & 100.00 \\
C3 & $42.00^{*}$ & 0.00 & 100.00 \\
C4 & $42.00^{*}$ & 0.00 & 100.00 \\
C2 & $42.00^{*}$ & 0.00 & 100.00 \\
C6 & $42.00^{*}$ & 0.00 & 100.00 \\
C5 & $42.00^{*}$ & 0.00 & 100.00 \\
C7 & 41.00 & 40.00 & 50.00 \\
C10 & 41.20 & 40.00 & 50.00 \\
C8 & 39.60 & 40.00 & 50.00 \\
C9 & 37.60 & 60.00 & 25.00 \\
Control & 32.80 & 80.00 & 0.00 \\
\hline
\end{tabular}

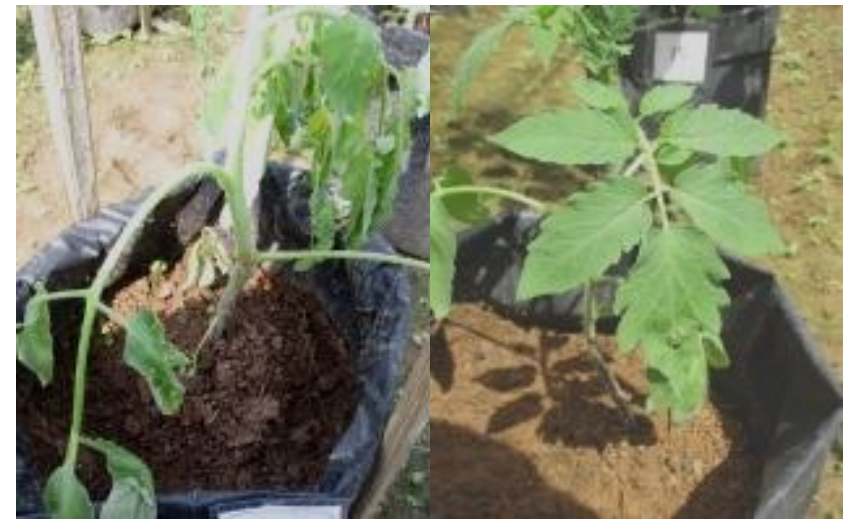

Figure 3. Ralstonia syzigii subsp. indonesiensis disease development on tomato treated with $\mathrm{C} 1$ consortium (right) and control (left)

Biocontrol activity against $R$. syzigii subsp. indonesiensis on tomato introduced with PGPR consortiums

Besides of having good abilities in promoting growth rate, the consortia also had good ability to suppress the infection of $R$. syzygii subsp. indonesiensis on tomato (Fig 3). Six out of ten consortia had the best ability in controlling the bacterial wilt disease, in which no symptoms developed on the plants until the last day of observations (Table 5). Those consortia were $\mathrm{C} 1, \mathrm{C} 2, \mathrm{C} 4$, C5, and C6.

\section{Discussion}

Microbial inoculants are promising components for integrated solutions to agro-environmental problems because inoculants possess the capacity to promote plant growth, enhance nutrient availability and uptake, and support the health of plants (Adesemoye et al. 2009). Our present study had shown that compatible strains developed 
as consortiums could increase plant growth and have biocontrol activity.

The combinations of PGPR strains consistently reduced the bacterial wilt disease of tomato under field conditions. The disease incidence varied from 0 to $60 \%$ (Table 5). No disease symptom was observed in the six consortia $(\mathrm{C} 1$, $\mathrm{C} 2, \mathrm{C} 3, \mathrm{C} 4, \mathrm{C} 5$, and C6) until the last day of observations. This showed a better result compared to the previous study that used single strain (Yanti et al. 2017). The results provide evidence that the compatibility of PGPR strains in the consortia effectively suppress disease development of R. syzygii subsp. indonesiensis. Combination of biocontrol agents is a strategic approach to control plant disease and pest (Nandakumar et al. 2001a; Latha et al. 2009). Furthermore, interactions among the bacterial strains may have synergistic effects that could induce systemically. These results could happen due to consortium may also improve their efficacy, reliability, and consistency under various soil and environmental conditions (Stockwell et al. 2010).

Our previous study showed that all the strain could inhibit disease development by $R$. syzigii subsp. Indonesiensis bythe increase of defense-related enzyme activity such as Phenylalanine ammonia lyase, Polyphenol oxidase, and peroxidase produced by the strains (Yanti et al. 2017). The inhibition of various plant pathogen and disease management by using several biocontrol agents through the induction of systemic resistance (ISR) in plants had reported in several bibliographies (van Loon and Bakker 2005; Saravanakumar et al. 2007). Increased activity of ISR induced by consortiums may be due to the increased number of strains involved in the treatment and moreover due to the cooperation among the strains.

In this study, the PGPR consortia increased plant height and leaf number of tomato (Table 3). The growth performances were better compared to the previous study using the single strain. This may occur due to the synergistic ability of the strains. All the strains used in this study can also produce indole acetic acid and some other PGPR traits such as solubilize phosphate (Yanti et al., 2017) that could lead to the plant growth promoting activity. Earlier reports had shown that combined inoculation of Azospirillum, Azotobacter chrococcum, Pseudomonas fluorescens and B. megaterium for sorghum was significantly increased grain yield. The stimulatory effects of this PGPR strains on the yield and growth of the crops were attributed to the $\mathrm{N} 2$ fixation ability, plant growth regulator production and phosphate solubilizing capacity (Cakmakci et al. 2007; Kevinvessey 2003; Karlidag et al. 2007; Salantur et al. 2006).

The consortiums could accelerate flowering and increase yields of tomato (Table 4). This effect may relate to the growth increase of the tomato. The yields also higher compared to the single strain inoculant. The beneficial effect of seed inoculation with bacterial consortia on the shoot, dry weight, and yield of maize was also reported by Shaharoona et al. (2006). Son et al. (2006) also found that combination treatment of rhizobacteria strains of Bradyrhizobium japonicum and Pseudomonas spp. could increase yield of soybean.
In conclusions, the application of PGPR consortiums found to be effective in controlling the bacterial wilt disease caused by $R$. syzygii subsp. indonesiensis. The present study clearly indicated that the combination of biocontrol agents showed the maximum effects on reduction of $R$. syzygii subsp. indonesiensis disease development, compared to individual agents used as the previous study suggesting the synergistic effect of consortiums against the pathogen. The PGPR combinations of C1 (S. nematodiphila strain DZ0503SBS1, B. toyonensis strain BCT-7112, B. aryabhattai strain B8W22, B. cereus strain IAM 12605), C2 ( $S$. nematodiphila strain DZ0503SBS1, B. toyonensis strain BCT-7112), C3 (B. aryabhattai strain B8W22, B. cereus strain IAM 12605), C4 (B. Pseudomycoides strain NBRC 101232, B. cereus strain CCM 2010, B. toyonensis strain BCT-7112, B. toyonensis strain BCT-7112), C5 (B. cereus strain CCM 2010 , B. toyonensis strain BCT-7112, B. toyonensis strain BCT-7112, B. aryabhattai strain B8W22) and C6 (B. cereus strain CCM 2010, B. toyonensis strain BCT-7112) were the promising consortia for the management of wilt disease and enhance the growth of tomato plants.

\section{ACKNOWLEDGEMENTS}

This research was funded by Research Funding Cluster "Riset Percepatan Guru Besar" with contract No. 21/UN.16.17/PP.PGBLPPM/2018 April 23, 2018, Universitas Andalas, Padang, Indonesia.

\section{REFERENCES}

Adesemoye A, Torbert H, Kloepper J. 2009. Plant growth-promoting rhizobacteria allow reduced application rates of chemical fertilizers. Microbiol Ecol 58: 921-929.

Bashan Y. 1998. Inoculants of plant growth promoting bacteria for use in agriculture. Biotechnol Adv 16:729-770

Cakmakci R, Donmez MF, Erdogan U. 2007: The effect of plant growth promoting rhizobacteria on barley seedling growth, some soil properties and bacterial counts. Tur J Agric For 31: 189-199.

Canaday C. 2003. Biological Control of Soil-Borne Plant Pathogens for Sustainable Agriculture. Annual Meeting of the Technical Committee S-302 Southern Regional Project, Ft. Lauderdale, FL. $23^{\text {rd }}$ November 2003

Horita M, Tsuchiya K. 2001. Genetic diversity of Japanese strains of Ralstonia solanacearum. Phytopathology 91: 399-407.

Jaleel CA, Manivannan P, Sankar B, Kishorekumar A, Gopi R, Somasundaram R, Panneerselvam R. 2007. Pseudomonas fluorescens enhances biomass yield and ajmalicine production in Catharanthus roseus under water deficit stress. Coll Surf B: Biointerfaces 60 (1): 711.

Ji P, Momol MT, Olson SM, Pradhanang PM, Jones JB. 2005. Evaluation of thymol as biofumigant for control of bacterial wilt of tomato under field conditions. Plant Dis 89: 497-500.

Karlidag HA, Esitken, Turan M, Sahin F. 2007: Effects of root inoculation of plant growth promoting rhizobacteria (PGPR) on yield, growth and nutrient element contents of apple. Scientia Horticulture 114: 1620 .

Karthikeyan M, Radhika K, Bhaskaran R, Mathiyazhagan S, Sandosskumar R, Velazhahan R, Alice D. 2008. Biological control of onion leaf blight disease by bulb and foliar application of powder formulation of antagonist mixture. Arch Phytopathol Plant Protect 41 (6): 407-417

Kevinvessey J. 2003. Plant growth promoting Rhizobacteria on Radishes, p. 879. Angers (Ed.) Gibert - Clarey, Tours. 
Kumar H, Dubey RC, Maheshwari DK. 2011. Effect of plant growth promoting rhizobia on seed germination, growth promotion and suppression of Fusarium wilt of fenugreek (Trigonella foenumgraecum L.). Crop Protect 30 (11): 1396-1403.

Latha P, Anand T, Ragupathi N, Prakasam, V, Samiyappan R., 2009. Antimicrobial activity of plant extracts and induction of systemic resistance in tomato plants by mixtures of PGPR strains and zimmu leaf extract against Alternaria solani. Biol Contr 50: 85-93.

Nandakumar R, Babu S, Viswanathan R, Raguchander T, Samiyappan R. 2001a. Induction of systemic resistance in rice against sheath blight disease by Pseudomonas fluorescens. Soil Biol Biochem 33: 603612.

Nandakumar R, Babu S, Viswanathan R, Sheela J, Raguchander T, Samiyappan R. 2001b. A new bio-formulation containing plant growth promoting rhizobacterial mixture for the management of sheath blight and enhanced grain yield in rice. BioControl 46 (4): 493-510.

Rajasekar S, Elango R. 2011. Effect of microbial consortium on plant growth and improvement of alkaloid content in Withania somnifera (Ashwagandha). Curr Bot 2 (8): 27-30.

Raupach GS, Kloepper JW. 1998. Mixtures of plant growth promoting rhizobacteria enhance biological control of multiple cucumber pathogens. Phytopathology 88: 1158-1164.

Safni I, Cleenwerck I, De Vos P, Fegan M, Sly L, Kappler U. 2014 Polyphasic taxonomic revision of the Ralstonia solanacearum species complex: proposal to amend the descriptions of Ralstonia solanacearum and Ralstonia syzygii and reclassify current $R$. syzygii strains as Ralstonia syzygii subsp. syzygii subsp. nov., $R$. solanacearum phylotype IV strains as Ralstonia syzygii subsp. indonesiensis subsp. nov., banana blood disease bacterium strains as Ralstonia syzygii subsp. celebesensis subsp. nov. and $R$. solanacearum phylotype I and III strains as Ralstonia pseudosolanacearum sp. nov. Intl J Syst Evol Microbiol 64 (9): 3087-3103.

Salantur A, Ozturk, A, Akten S. 2006. Growth and yield response of spring wheat (Triticum aestivum L.) to inoculation with rhizobacteria. Plant Soil Environ. 52: 111-118.
Saravanakumar D, Vijayakumar C, Kumar N, Samiyappan R. 2007. PGPR-induced defense responses in the tea plant against blister blight disease. Crop Protect 26 (4): 556-565.

Shaharoona B, Arshad M, Zahir ZA, Khalid A. 2006. Performance of Pseudomonas spp. containing ACC-deaminase for improving growth and yield of maize (Zea mays L.) in the presence of nitrogenous fertilizer. Soil Biol Biochem 38: 2971-2975.

Shenoy VV, Kalagudi GM. 2003. Meta-bug and near-isogenic strain consortia concepts for plant growth promoting rhizobacteria. In: 6 International PGPR Workshop, India, Section VII: Mechanism of Biocontrol.

Sivan A, Chet I. 1989. Degradation of fungal cell walls by lytic enzymes of Trichoderma harzianum. Microbiology 135 (3): 675-682.

Stockwell VO, Johnson KB, Sugar D, Loper JE. 2010. Mechanistically compatible mixtures of bacterial antagonists improve biological control of fire blight of pear. Phytopathology 101:113-123.

Son TTN, Diep CN, Giang TTM. 2006. Effect of bradyrhizobia and phosphate solubilizing bacteria application on Soybean in rotational system in the Mekong delta. Omonrice 14: 48-57.

Sundaramoorthy S, Raguchander T, Ragupathi N, Samiyappan R. 2012. Combinatorial effect of endophytic and plant growth promoting rhizobacteria against wilt disease of Capsicum annum L. caused by Fusarium solani. Biological Control 60(1): 59-67.

Thilagavathi R, Saravanakumar D, Ragupathi N, Samiyappan R. 2007. A combination of biocontrol agents improves the management of dry root rot (Macrophomina phaseolina) in greengram. Phytopathologia Mediterranea 46 (2): 157-167.

Van Loon LC, Bakker PAHM. 2005. Induced systemic resistance as a mechanism of disease suppression by rhizobacteria. In: PGPR: Biocontrol and Biofertilization. Springer, Dordrecht.

Yanti Y, Astuti FF, Habazar T, Nasution CR. 2017. Screening of rhizobacteria from rhizosphere of healthy chili to control bacterial wilt disease and to promote growth and yield of chili. Biodiversitas 18 (1): $1-9$.

Yanti Y, Warnita, Reflin, Busniah M. 2018a. Indigenous endophyte bacteria ability to control Ralstonia and Fusarium wilt disease on chili pepper. Biodiversitas 19 (4): 1532-1538. 